\title{
DEVELOPMENT OF MODERN EDUCATIONAL APPROACHES WITH A VIEW TO INCLUSION OF THE EDUCATION AREA IN SERBIA IN THE EUROPEAN HIGHER EDUCATION AREA
}

\author{
Milan Počuča ${ }^{1}$ \\ Jelena Matijašević-Obradović
}

DOI: https://doi.org/10.31410/ERAZ.S.P.2019.141

\begin{abstract}
Intensive development of Information-Communication Technologies (ICT) provides a favourable technical and technological basis for modern approaches in education. In the European and generally worldwide education area, two quite represented modern approaches to education are Open Educational Resources (OER) and Distant Learning System (DLS). The scope of this work is the notional establishment and survey of the importance of implementation of both concepts in the area of education, as well as analysis of the implementation of DLS in the higher education in Serbia as an important step to inclusion of the educational area of Serbia in the European Higher Education Area (EHEA). The conclusion which is derived on the basis of the analysis of available data of Commission for Accreditation and Testing of Quality (CATQ) is that DLS study programmes are not represented to a larger extent in the system of higher education of Serbia.
\end{abstract}

Keywords: higher education, OER, DLS, EHEA.

\section{INTRODUCTION}

$\mathrm{T}$

he modern system of education has been facing numerous challenges since the $90 \mathrm{~s}$ of the $20^{\text {th }}$ century, to the present day. The opportunity for changes in the manner of presenting the teaching content has been created through the expansive development, implementation and wide availability of ICT. Over the past few years the education system has actively included information technology support in the teaching process. Under such circumstances significant changes in the European higher education system inevitably took place. At present, however, one of the goals of united Europe is certainly the creation of a European society of knowledge that is based on two pillars - the European Research Area - ERA, and the European Higher Education Area - EHEA.

In the European and generally worldwide education area, two highly represented modern approaches to education are the concept of Open Educational Resources (OER) and the concept of the Distance learning System (DLS). In its basic interpretation the OER concept encompasses every educational resource that is publicly available for use by teachers and students with nocost access. The DLS is a concept that, in a broader sense, can be subsumed under the OER concept because it is a form of learning that is based on the implementation of ICT, especially the Internet, as a global computer network, thus also implying, among other things, physical distance between students and teachers, an organisation that provides the teaching content in electronic form and its delivery in electronic form, and (mostly) an interactive realisation of classes by means of information technology.

\footnotetext{
Faculty of Law for Commerce and Judiciary, University Business Academy, Geri Karolja 1, Novi Sad, Serbia
} Faculty of Law for Commerce and Judiciary, University Business Academy, Geri Karolja 1, Novi Sad, Serbia 
The aim of this paper is to conceptually determine and understand the importance of applying both concepts in the field of education, to consider the possibilities for application and the very application of modern approaches in education in Serbia as an important step in including Serbia's education area in the European Higher Education Area.

\section{THE CONCEPT AND IMPORTANCE OF OER AND DLS}

As the name of the concept indicates, OER implies openness and accessibility of educational resources. As Mossley [1] states, the key idea of OER is openness in creating, sharing and reusing teaching materials, with as little cost as possible for accessing these materials that the student or end user would have to pay.

OER has emerged as a concept with great potential to support educational transformation. While its educational value lies in the idea of using resources, that is, in supporting learning based on a large number of available resources, its power in the field of transformative education lies in the ease with which such resources, when digitized, can be shared via the Internet. [2]. Larsen and Vincent-Lancrin [3] join the authors who stress the advantages of the OER concept over any other educational concept. According to them, the main argument in favour of the OER concept is that OER can be described as an innovative practice that provides a good example of the use of current opportunities and challenges offered by ICTs in order to trigger radical innovations in pedagogical work. Digitalization and its current potential, the financially affordable possibility of global communication, have opened tremendous new opportunities for the use, dissemination and exchange of learning material.

The benefits of the OER concept can also be understood by looking at the impact on the users in an OER network. For authors, publications with open and allowed access, i.e. those accessible to everyone, have the widest possible audience, or circle of users. Studies show that their articles are cited more frequently. For readers, on the other hand, open access grants access to an entire body of literature, not requiring permission or compensation. Finally, for publishers, open access to publications guarantees the widest dissemination, i.e., use by users, of their published articles and books [4].

The OER concept has largely alleviated and overcome the significant limitations of the traditional approach in the field of education, especially in the field of higher education. The possibilities that OER has introduced into the education system have radically changed the attitude of not only the students, but also of the teaching staff and staff at colleges and universities, towards the educational process, interaction and communication in the higher education system. According to Butcher: "the OER's transformative educational potential revolves around three interconnected perspectives: 1 . Increase in the accessibility of relevant high-quality learning resources can contribute to a higher productivity of students and teachers alike; 2 . The principle of allowing material adaptations has provided one of many mechanisms of giving the students the role of active participants in educational processes; 3. OER provides institutions and teachers with free or reasonably priced access to the necessary resources, in order to improve their skills in creating teaching materials, and integrating such materials in learning programmes" [2].

In analysing the application of the DLS concept in the higher-education area in Serbia, Milunovic and Ćurčić quote that DLS is "a completely new form of education, in which information technologies act as an intermediary in the contacts of teachers and users who are not at the same place at a previously defined period of time" [5], while Tepšić and associates point out that "contemporary information-communication technologies (the Internet, computer networks, digitalization, etc.) have turned distance learning into a primary concept in acquiring open knowledge. Distance learning 
may be a supplement to traditional education, or a replacement for traditional education" [6]. When speaking of the traditional models of teaching and learning, and of the model which has only in recent years been gaining ground in our country - the DLS model, we cannot ignore several important factors which largely influence the acceptance of a certain approach. Namely, what strongly affects the way a society reacts to innovations not only in the field of education, but other areas of life and work as well, is the value system promoted in that society, and the cultural and motivational aspects. No less significant is the social aspect. This means that the preference for a particular approach in the education system is not only dependent on the comparison of the good and bad sides of the approach, but also on our society's capacities and willingness to understand, comprehend and objectively assess the advantages of a certain model of teaching and learning, and apply it in accordance with that assessment [7]. DLS undoubtedly has numerous advantages compared to the traditional approach in teaching and education, as quoted by Stanić and Gavrilović [8]: temporal and spatial flexibility, student - teacher interaction taking place online (email, forums) is often more direct and intense than communication during lectures; using interactive learning resources.

Besides the advantages mentioned above, in favour of the DLS concept we may also quote the possibility of attending prestigious courses of study in high-quality educational institutions, held by acclaimed experts, without changing one's place of residence, then the acquisition of additional skills and knowledge on the use of modern information technology, building independence in seeking information sources, etc. All the aforesaid advantages are of great help to students, and represent a strong motivation for learning and improvement, in particular with regard to the financial aspect, as the practice demonstrates that the DLS approach is more easily accessible than any one of its traditional equivalents.

\section{THE INITIATIVES OF OER AND DLS DEVELOPMENT IN EUROPE AND WORLDWIDE}

Based on investigating OER application in higher education in European Union universities, we can conclude that there are numerous initiatives in the field of higher education which are focused on promoting publicly accessible education for learning and teaching. The table that follows lists the most important initiatives of OER development in the field of higher education in Europe, as well as the initiatives existing in the region and in Serbia.

A lot of effort has been invested in the development of DLS in Europe and on the global level. A large number of world-famous higher-education institutions incorporate this form of education in their programmes of studies. According to the data of The United States Distance Learning Association (USDLA) for 2003, "some of the most important institutions that apply it in their work in the USA are: National Technological University, Western Governors University, University of Phoenix, California Distance Learning Program, Columbia Network for Engineering Education; in Europe: The International Council for Open and Distance Education - Oslo, United Kingdom Open University, Virtual University Enterprises, University for Industry, etc.“ [10].

The same author also states that significant distance learning development initiatives in Europe have been realized through the European Distance Education Network - EDEN and the European Association of Distance Education Teaching Universities, while the European Commission in its documents (E-learning Action Plan 2004-2006) strongly supports the development of distance learning, i.e. e-education in all the EU member states. The EDEN members from Serbia are: The E-Learning Network, the Link Group (which is the incorporator of the Belgrade Academy of Computer Sciences), and the Faculty of Economics of Subotica [10]. 
Table 1. Initiatives of OER development in the field of higher education in Europe, the region and Serbia [9]

\begin{tabular}{|l|l|l|}
\hline Europe & Region & Serbia \\
\hline $\begin{array}{l}\text { Open Education Europa - part } \\
\text { of the European consortium on } \\
\text { publicly available educational } \\
\text { programmes }\end{array}$ & $\begin{array}{l}\text { Be an Engineer - Faculty of } \\
\text { Architecture and Civil Engineering } \\
\text { of the University of Banja Luka }\end{array}$ & $\begin{array}{l}\text { Knowledge is All - "Svetozar } \\
\text { Marković” University Library in } \\
\text { Belgrade }\end{array}$ \\
\hline Miriada X - Spain & - & $\begin{array}{l}\text { DLS - LINKgroup Company, } \\
\text { Belgrade }\end{array}$ \\
\hline iMOOC - Portugal & - & \\
\hline $\begin{array}{l}\text { FutureLearn as a branch of Open } \\
\text { University and JORUM - Great } \\
\text { Britain }\end{array}$ & - & - \\
\hline Alison and IREL-Open - Ireland & - & \\
\hline $\begin{array}{l}\text { FUN (fr. France Université } \\
\text { Numérique) - France }\end{array}$ & - & - \\
\hline Eliademy - Finland & - & - \\
\hline
\end{tabular}

\section{THE STRATEGIC FRAMEWORK FOR THE APPLICATION OF MODERN APPROACHES IN EDUCATION IN SERBIA}

The starting point for the application of the OER and DLS concepts in Serbia is the Strategy for Education Development in Serbia to 2020 [11], which is based on the openness of education.

The mission of Serbia's education system in the $21^{\text {st }}$ century is to ensure the basic foundation of life and development of each individual, the society, and the country as a whole, which is based in knowledge [11].

According to Ćamilović, "as one of the measures, the Strategy provides support to a greater use of e-learning methodology and technologies as an addition to traditional learning, through the development of courses of study which are provided in parallel (both in the classic form, and as distance studies), and courses of study which are only realised as distance studies, provided that the quality standards for distance studies should be harmonised with global and EU practices. The importance of distance learning courses and e-learning programmes has been recognised in adult education, as well as the potential for using distance learning resources to ensure accessibility of education to persons with developmental disabilities" [12].

\section{ANALYSING THE APPLICATION OF THE DLS CONCEPT IN COLLEGES, FACULTIES AND UNIVERSITIES IN SERBIA}

Following the theoretical introduction and consideration of the importance of OER, and DLS in particular as the most widespread OER initiative, and following the analysis of the most significant developmental initiatives associated with these modern approaches in Europe and globally, as well as the strategic framework, and the possibilities of applying the modern approaches to education in Serbia, we should briefly analyse the current situation in Serbia with regard to the actual presence of the DLS concept in the higher education system. In other words, the question is to what extent is the concept of distance studies being applied in teaching in the courses of study of colleges, faculties and universities. 
More specifically, we should analyse the following aspects: 1) the relative presence of distance study courses between colleges (of academic and applied studies), faculties and universities (having specifically in mind the studies organised and carried out in universities) 2) the relative presence of distance study courses between the universities and faculties founded by the Republic of Serbia, and the universities and faculties not founded by the Republic; 3) the presence of courses of distance studies in relation to the total number of the study courses realised in all the faculties and universities in Serbia.

The analyses presented in the following tables have been conducted based on the official data of the Commission for Accreditation and Quality Assurance, and they have included all the current courses of study, both those which have not yet entered the reaccreditation process, and those which have completed the process with success. The analyses have not included the study courses which were accredited in the first (initial) accreditation cycle, and which gained a new Accreditation Certificate in the reaccreditation cycle. The data on which the analyses are based were updated by the Commission to 31 March 2017. The methodological framework of the paper primarily includes the analytic method, the deductive method, and a basic quantitative analysis of data.

Table 2. The presence of DLS study courses in universities in Serbia [13]

\begin{tabular}{|l|c|c|c|}
\cline { 2 - 4 } \multicolumn{1}{c|}{} & \multicolumn{2}{c|}{ Universities in Serbia-university studies } & \multirow{2}{*}{ Total: } \\
\cline { 2 - 4 } & $\begin{array}{c}\text { Universities founded by } \\
\text { the Republic }\end{array}$ & $\begin{array}{c}\text { Universities not founded } \\
\text { by the Republic }\end{array}$ & \\
\hline DLS - Academic Bachelor studies & $/$ & 8 & 3 \\
\hline DLS - Academic Master studies & $/$ & 3 & 11 \\
\hline
\end{tabular}

Table 3. The presence of DLS study courses in faculties in Serbia [13]

\begin{tabular}{|l|c|c|c|}
\cline { 2 - 4 } \multicolumn{1}{c|}{} & \multicolumn{2}{c|}{ Faculties in Serbia } & Total: \\
\cline { 2 - 4 } \multicolumn{1}{c|}{} & $\begin{array}{c}\text { Faculties founded by the } \\
\text { Republic }\end{array}$ & $\begin{array}{c}\text { Faculties not founded by } \\
\text { the Republic }\end{array}$ & \\
\hline DLS - Specialist academic studies & 1 & $/$ & 1 \\
\hline DLS - Academic Bachelor studies & 1 & 18 & 19 \\
\hline DLS - Academic Master studies & 2 & 7 & 9 \\
\hline DLS - Applied Bachelor studies & 1 & 25 & 30 \\
\hline
\end{tabular}

Table 4. The presence of DLS study courses in colleges in Serbia [13]

\begin{tabular}{|l|c|c|c|}
\cline { 2 - 4 } \multicolumn{1}{c|}{} & \multicolumn{2}{c|}{ Colleges in Serbia } & \multirow{2}{*}{ Total: } \\
\cline { 2 - 4 } \multicolumn{1}{c|}{} & $\begin{array}{c}\text { Colleges of academic } \\
\text { studies }\end{array}$ & $\begin{array}{c}\text { Colleges of applied stud- } \\
\text { ies }\end{array}$ & \\
\hline DLS - Academic Bachelor studies & $/$ & $/$ & $/$ \\
\hline DLS - Academic Master studies & $/$ & $/$ & 1 \\
\hline DLS - Applied Bachelor studies & $/$ & 11 & 1 \\
\hline DLS - Applied Specialist studies & $/$ & 1 & 12 \\
\hline
\end{tabular}

Taking a closer look at the presented data, we become aware of several things. First, no college of academic studies has accredited a DLS course of study, whereas 12 distance study courses have been accredited by colleges for applied studies, 11 of which are in applied bachelor studies, and 1 course of study in specialist applied studies. The ratio of the number of accredited courses of study for distance studies between colleges on one side, and faculties and distance studies organised in universities, on the other side, approximates 1:3.5. 
Second, it is noticeable that the number of accredited courses of study for distance studies in the faculties and universities not founded by the Republic is seven times higher than the number of courses of study for distance studies in the faculties and universities founded by the Republic. To be exact, the ratio of the number of accredited distance study courses between the faculties and universities founded by the Republic and those not founded by the Republic is 1:7.2.

Third, the universities founded by the Republic, which organise and carry out studies at the university, have in fact no DLS course of study available to potential students. As opposed to them, the universities not founded by the Republic have 11 accredited DLS courses of study, 8 of which in academic bachelor studies, and 3 DLS courses in academic master studies.

Fourth, the faculties founded by the Republic have 5 accredited DLS courses of study, i.e. 1 study course in specialist academic studies, 1 in academic bachelor studies, 2 study courses in academic master studies, and 1 course of study in applied bachelor studies. The faculties not founded by the Republic have 25 accredited DLS courses of study, 18 of which in academic bachelor studies, and 7 courses of study in academic master studies. This data and the information provided above indicate that the universities and faculties not founded by the Republic of Serbia are much more willing to adopt new educational approaches, without being "a slave" to decades-old, traditional (classical) approaches to teaching.

Fifth, if we compare the total number of accredited DLS courses of study in all the faculties, universities and colleges of Serbia (53 DLS courses of study in total) with the number of all the universities (18), faculties (around 140) and colleges (around 80) and the courses of study accompanying the concept of traditional (classical) approach to education (over 1,770), we can see that a very small number of faculties / universities / colleges have decided in favour of the introduction of the DLS concept in certain courses of study, with the institutions for the most part opting for accrediting one or two courses of study per institution.

\section{CONCLUSION}

The intensive development of electronics, computers, telecommunications, and other ICT components provides a fitting technical and technological foundation to modern approaches in education, which contribute to the improvement of teaching, student motivation, raising the quality of learning, etc. The OER concept functions very successfully in a large number of countries, in particular the most highly developed countries on the global level. In line with that, a large quantity of educational resources within OER, which are promoted for purely educational, non-commercial purposes, have in recent years been accessible worldwide, while the Open Educational Resources are growing in capacity on a weekly and monthly basis.

What can undeniably be classified as a significant advantage of distance learning is the fact that students lose nothing in terms of the quality of teaching and the scope of knowledge they acquire through distance learning, while on the other hand they are given an opportunity to study at their own pace, at the time that best suits them, from home, which makes it easier for them to fit their studies alongside other responsibilities of everyday life. A properly established DLS system (in terms of technology, human resources, organisation, etc.), adequate teaching materials, and the correct approach of teachers in communicating relating to distance learning, may greatly contribute to the achievement of several crucial objectives of long-term development of education in the context of the Strategy for Education Development. 
In Serbia, the application of OER is at the very beginning. There is a very small number of initiatives which would expand and intensify the application of this modern approach. Only in the years that follow can we expect any significant steps forward in the number and types of initiatives which would contribute to a further development and strengthening of OER. As is evident from CATQ's analysis of available data, DLS courses of study are not overly represented in the higher education system of Serbia. In other words, a rather small number of higher education institutions have decided to accredit any DLS courses of study, primarily in bachelor or master academic studies. The presented data lead to the conclusion that a much higher representation of modern educational approaches is required in Serbia, in particular in the higher education segment. A faster development and improvement of DLS is certainly highly demanding work, first of all an organisational challenge, owing to which many faculties and universities are compelled to change the traditional educational approach, which was practically inconceivable a few years ago.

With regard to the aforesaid, further research is required with a view to defining the ways of change of the current situation in terms of the application of modern approaches in education, primarily OER and DLS in higher education institutions in Serbia, which is certainly an essential and very significant step in harmonising the educational area of Serbia with the EU's higher education area.

\section{REFERENCES}

[1] Mossley, D. (2013) Open Educational Resources and Open Education. United Kingdom, Heslington: The Higher Education Academy (HEA), p. 11.

[2] Butcher, N. (2015) A Basic Guide to Open Educational Resources (OER). France: United Nations Educational, Scientific and Cultural Organization (UNESCO) and Canada: Commonwealth of Learning, p. 5-13.

[3] Larsen, K., Vincent-Lancrin, S. (2006) The impact of ICT on tertiary education: advances and promises. In B. Kahin \& D. Foray (Eds.), Advancing Knowledge and the Knowledge Economy, Washington, Cambridge, Massachusetts: MIT Press, 151-168, pp. 164-165.

[4] Downes, S. (2006) Models for Sustainable Open Educational Resources. Canada: National Research Council, p. 2.

[5] Milunović, S., Ćurčić, S. (2012) Metodika obrazovanja iz oblasti tehnike zasnovana na primeni učenja na daljinu [=The Methods of Education in the Field of Engineering Based on Distance Learning]. In D. Golubović (Ur.), IV Internacionalna konferencija - Tehnika i informatika u obrazovanju, Čačak: Tehnički fakultet Čačak Univerziteta u Kragujevcu, 512-518, p. 513.

[6] Tepšić, M., Borovnica, T., Bakić, S. (2015) Sistemi za elektronsko testiranje znanja studenata [= The Systems of Electronic Student Knowledge Testing]. Primus global-ekonomija, informatika, pravo, 1 (1), 1-10, p. 2.

[7] Matijašević-Obradović, J., Joksić, I. (2014). Zastupljenost koncepta učenja na daljinu u sistemu visokog obrazovanja u Srbiji [= The Representation of the Distance Learning Concept in the Higher Education System in Serbia], Nastava i vaspitanje, 63 (1), 145-158, p. 149.

[8] Stanić, N., Gavrilović, J. (2011). Komparativna analiza sistema učenja na daljinu [= A Comparative Analysis of the Distance Learning System]. In VIII Naučni skup sa međunarodnim učešćem Sinergija, Bijeljina: Univerzitet Sinergija, 139-143, pp. 140-141.

[9] Izveštaj sa Tempus projekta BAEKTEL - Spajanje akademskog i preduzetničkog znanja kroz tehnološki potpomognuto učenje. (2014). DEV 1.1 Analiza postojeće evropske prakse i principa u razvoju otvorenih obrazovnih resursa (OER) $[=$ Report from the BAEKTEL 
Tempus Project - The Merging of Academic and Entrepreneur Knowledge Through Technologically Aided Learning]. Project No.: 544482-TEMPUS-1-2013-1-IT-TEMPUS-JPHES, pp. 12-20.

[10] Pokorni, S. (2009). Obrazovanje na daljinu [= Distance Learning]. Vojnotehnički glasnik, br. 2, 138-146, p. 138.

[11] Strategija razvoja obrazovanja u Srbiji do 2020. godine (2012) [= The Strategy for Education Development in Serbia to 2020 (2012)]. Službeni glasnik Republike Srbije, broj $107 / 2012$.

[12] Ćamilović, D. (2013). Visokoškolsko obrazovanje na daljinu [= Higher Education at a Distance], Tranzicija, 15 (31), 29-39, p. 36.

[13] Komisija za akreditaciju i proveru kvaliteta (2017) [= Commission for Accreditation and Quality Assurance]. Vodič kroz akreditovane visokoškolske ustanove i studijske programe u Republici Srbiji, p. 5-60, available at: https:/drive.google.com/file/d/0Bwr8qEMuakSJS0E3SnNRdDFVdUE/view (27.04.2017.) 